\title{
Erratum to: Association of life course socioeconomic disadvantage with future problem drinking and heavy drinking: gender differentials in the west of Scotland
}

\author{
G. David Batty • Abita Bhaskar · Carol Emslie • \\ Michaela Benzeval · Geoff Der · Heather Lewars • \\ Kate Hunt
}

Published online: 23 August 2011

(C) Swiss School of Public Health 2011

Erratum to: Int J Public Health

DOI 10.1007/s00038-011-0270-8

Unfortunately, the corresponding author's name was rendered wrongly in the addresses. Instead of G. David Batty it should read: G. D. Batty.

The online version of the original article can be found under doi:10.1007/s00038-011-0270-8.

G. D. Batty $(\bowtie)$

Department of Epidemiology and Public Health,

UCL, 1-19 Torrington Place, London WC1E 6BT, UK

e-mail: david.batty@ucl.ac.uk

G. D. Batty - A. Bhaskar - C. Emslie - M. Benzeval - G. Der ·

H. Lewars - K. Hunt

Medical Research Council Social and Public Health Sciences

Unit, Glasgow, UK 